\title{
ADULT AGE IN MARRIAGE IN INDONESIA (Theoretical Study of the Application of the Lex Posterior Derogat Legi Priori Principle)
}

\author{
Taufik H. Simatupang \\ Research and Development Board for Law and Human Rights \\ Corresponding email: taufikhSimatupang73@gmail.com
}

Paper received on: 27-01-2021; Revised on: 03-05-2021; Approved to be published on: 04-05-2021

DOI: http://dx.doi.org/10.30641/dejure.2021.V21.213-222

\begin{abstract}
The problems to be answered in this research are, first, how is the regulation of Islamic family law and marriage in Indonesia, second, how is underage marriage and legal protection for children, third is how to apply the lex posterior derogat legi priori principle in determining the adult age for marriage. The research method used is normative juridical research with a statute approach which was analyzed using statutory principles. The results of the research concluded that Islamic family law cannot be separated from the history of the legal system in Indonesia from the time of Dutch colonialism to the present which involved three parties, namely the interests of religion, the state and women. Underage marriage is influenced by economic problems, parental coercion and community culture. Based on the lex posterior legi priori principle, the age limit of a child must be seen in the context of what the maturity measure is to be used. If the maturity is for a marriage, then the adult age limit is 19 years, for both women and men. Although in the future it is suggested that further research is needed regarding the financial maturity of men who are married at the age of 19.
\end{abstract}

Keywords: adult; marriage; legal principle

\section{INTRODUCTION}

According to research results, the legal age limit in Indonesia is regulated in several laws and regulations. Article 330 of the Civil Code (KUHPerdata) states that adults must be 21 years old. Law No. 16 Year 2019 concerning Amendments to Law Number 1 Year 1974 concerning Marriage, adults aged 18 years². Law Number 23 Year 2002 Concerning Child Protection, the adult category is 18 years old ${ }^{3}$. According to the Islamic Law Compilation (KHI), the adult age is 21 years $^{4}$. Law Number 30 Year 2004 concerning Notary Position, adults aged 18 years 5 . Law Number 39 Year 1999 concerning Human Rights (HAM), adults aged 18 years $^{6}$. Law

F.M. Bukido, R. \& Wantu, "Synchronize the Different Law Rules Study of Law Number 16 Year 2019 and Law Number 35 Year 2014," Journal of Legal, Ethical and Regulatory Issues 23 (2020): 1-9.

2 Lihat Pasal 47 Ayat (1) Undang-Undang Nomor 16 Tahun 2019 Tentang Perubahan Undang-Undang Nomor 1 Tahun 1974 Tentang Perkawinan, n.d.

3 Lihat Pasal 1 Ayat (1) Undang-Undang Nomor 23 Tahun 2002 Tentang Perlindungan Anak, n.d.

4 Lihat Pasal 98 Ayat (1) Instruksi Presiden Nomor 1 Tahun 1991 Tentang Kompilasi Hukum Islam, n.d.

5 Lihat Pasal 39 Dan Pasal 40 Undang-Undang Nomor 30 Tahun 2004 Tentang Jabatan Notaris, n.d.

6 Lihat Pasal 1 Angka 5 Undang-Undang Nomor 39 Tahun 1999 Tentang Hak Asasi Manusia, n.d.
Number 11 Year 2012 concerning the Criminal Justice System for Children, adults aged 18 years, ${ }^{7}$ and Law Number 13 Year 2003 concerning Manpower states that the adult age is 18 years $^{8}$

From the regulations of these laws, in Indonesia the adult age limit is regulated differently as in the table below:

Table. 1.1. Adult According to Laws and Regulations in Indonesia

\begin{tabular}{|l|c|}
\hline \multicolumn{1}{|c|}{ Legal Basis } & Adult Age Limit \\
\hline The Civil Code & 21 years \\
\hline Law Number 16 year 2019 & 18 years \\
\hline Law Number 35 year 2014 & 18 years \\
\hline Islamic Law Compilation & 21 years \\
\hline Law Number 30 year 2004 & 18 years \\
\hline Law Number 39 year 1999 & 18 years \\
\hline Law Number 11 year 2012 & 18 years \\
\hline Law Number 13 year 2003 & 18 years \\
\hline
\end{tabular}

The regulation and determination of the age limit for adults which is regulated differently in the laws and regulations has an impact on the debate over which law should be used, as well as on what age limit one can actually be called an adult. This is important because maturity is a requirement to be able to get married.

7 Lihat Pasal 1 Angka 4 Dan Angka 5 Undang-Undang Nomor 11 Tahun 2012 Tentang Sistem Peradilan Pidana Anak, n.d.

8 Lihat Pasal 1 Angka 26 Undang-Undang Nomor 18 Tahun 2003 Tentang Ketenagakerjaan, n.d. 
In formal juridical terms, with the enactment of Law Number 1 Year 1974 concerning Marriage, the aim was to regulate marriage with all the aspects that arise in it, previously regulated in the Civil Code which was deemed incompatible with the spirit and personality of the religious Indonesian nation ${ }^{9}$. At the same time all the regulations in the field of marriage can be viewed as a national marriage law that applies to all regions and citizens of Indonesia ${ }^{10}$.

With the passing of Law Number 16 Year 2019 concerning Amendments to Law Number 1 Year 1974 concerning Marriage, the marriage age limit is 19 years for women and men. Psychologically, at that age people are adult enough and physically and emotionally mature.

However, actually entering the institution of marriage is not enough with psychological readiness and physical and emotional maturity; it also requires financial (economic) readiness. This is important because in Indonesia there is a high rate of divorce, one of which is due to financial (economic) problems. In general, a 19-year-old male wants to get the best achievement, both in education and career. Marriage at this age will tend to be more burdensome for men because they are not financially secure.

From the background description above, this research intended to analyze and answer several identified problems, namely about how Islamic family law and marriage in Indonesia are regulated, how underage marriage and legal protection for children are and how the application of the lex posterior derogat legi priori principle in determining mature age to get married is.

\section{RESEARCH METHOD}

This research used a normative juridical method, namely research conducted using secondary data in the form of formal legal norms related to family law in the field of marriage in terms of determining the age limit for marriage. The age limit for marriage, for one thing, is determined by the limit of a person's maturity.

\footnotetext{
9 Taufik H. Simatupang, "Disharmoni Peraturan PerundangUndangan Di Bidang Pengawasan Perwalian Di Indonesia (Lintas Sejarah Dari Hukum Kolonial Ke Hukum Nasional)," Jurnal Penelitian Hukum DE JURE 20, no. 2 (2020): 221-232.

1o Evi Djuniarti, "Perkawinan 'Padagelahang' Serta Asepk Hukum Pembagian Harta Warisannya Di Bali," Jurna Penelitian Hukum DE JURE 20, no. 3 (2020): 459-471.
}

Maturity is regulated differently in various laws and regulations in Indonesia. This research used a statute approach with specifications for the application of statutory principles and data collection was carried out through literature study. The data were analyzed using qualitative juridical method described in the form of explanation using legal interpretation and application of relevant legal principles, then deductive logic was drawn by presenting some of the data in a casuistic nature.

\section{DISCUSSION AND ANALYSIS}

\section{A. Islamic Family Law and Marriage in Indonesia}

According to science, civil law in Indonesia, which was inherited from the Netherlands, is divided into 4 (four) parts ${ }^{11}$, namely:

1. Law concerning persons or individual law, which regulates people as legal subjects and persons in their ability to have rights and act independently to exercise their rights.

2. Kinship law or family law which includes marriage, divorce and legal relations that arise therein, such as the law on assets between husband and wife, legal relations between parents and children or parental powers and guardianship.

3. Property law or asset law which regulates legal relations that can be valued in money, which includes absolute rights, namely rights that apply to everyone, individual rights, namely rights that only apply to a certain person or party.

4. The law of inheritance (erfrecht) regulates the asset or property of a person if he/she dies (regulates the legal consequences of family relationships on the inheritance someone has left behind).

Talking about family law in Indonesia cannot be separated from talking about Islamic family law, considering that the majority of Indonesian people are Muslim. Speaking of the Islamic family law that applies in Indonesia, it cannot be separated from the history of the legal system in Indonesia from the time of Dutch colonialism to the present. Interestingly, throughout Indonesian history, the discourse on family law includes marriage law in

\footnotetext{
" Y.T. Masriani, Pengantar Hukum Indonesia (Jakarta: Sinar Grafika, 2004).
} 
general, involving at least three parties, namely the interests of religion, the state and women.

Most Muslims, for example, where the majority of the Indonesian people embrace Islam, always feel they must be responsible for their followers, which is manifested by an effort to include Islamic law in Indonesia ${ }^{12}$. The part of family law that is often discussed is about marriage. Marriage according to Law Number 1 Year 1974 is a physical and mental bond between a man and a woman as husband and wife with the aim of forming a happy and eternal family (household) based on belief in the Almighty God.

The definition of marriage in terms of Islamic law is a contract/agreement to legalize sexual relations between men and women in order to realize the happiness of family life which is covered by a sense of peace and affection that is blessed by Allah SWT ${ }^{13}$. According to his nature, man is equipped with God with sexual inclination (sexuality libido). Therefore, God has provided a legal platform for this channeling to be carried out in accordance with the degree of humanity. However, marriage is not intended solely to fulfill this biological desire. If only that, the purpose of marriage has the same values as marriage adopted by biology, namely bringing together males and females to simply meet the generation reproduction need. Islam-taught marriage includes multiple aspects ${ }^{14}$.

Among the aspects of marriage when formulated there are various aspects. First, the personal aspect. In the personal aspect, there is channeling of biological needs and procreation. As Allah says in surah Ash-Shuraa (42): 49-50 reads:

To Allah alone belongs the kingdom of the heavens and the earth. He creates whatever He wills. He blesses whoever He wills with daughters, and blesses whoever He wills with sons, or grants both, sons and daughters, to whoever He wills, and leaves whoever He wills infertile. He is indeed All-Knowing, Most Capable.

12 Romlah R, "Pembaruan Hukum Keluarga Islam Di Indonesia Tentang Keabsahan Akad Bagi Wanita Hamil,” Jurnal AlAdalah Institut Agama Islam Negeri Raden Intan Lampung 13, no. 1 (2016): 23-38.

13 Mulyadi, Hukum Perkawinan Islam (Semarang: Badan Penerbit Universitas Diponegoro, 200o).

14 R. Hakim, Hukum Perkawinan Islam (Bandung: Pustaka Setia, 2000).
Second, the social aspect. The social aspect that is built from marriage is the desire for a good household as the foundation of a good society. Because with marriage, humans will be united in harmony, united to face the challenges of navigating the ark of life. So that it will lead to serenity in worship. It is only the elements that the Koran calls mawaddah and rohmah, that is what causes them to be so strong across this ark of life. In addition, other social aspects of marriage make people creative. Because, marriage also teaches us the responsibility for all the consequences that arise because of it. From this sense of responsibility and feeling of affection for the family arises the desire to change things for the better in various ways. People who are married always try to make their families happy. This encourages him to be more creative and productive, unlike when he was single.

Third, the ritual aspect, namely following the Prophet's sunnah and carrying out the orders of Allah SWT. Prophet Muhammad SAW ordered his people to get married as mentioned in the hadith:

But I myself prayed, slept, I fasted and also broke, I married women. Who is not happy with my sunnah, then he is not from my group.

Likewise, Allah commands marriage when you are able. The Word of Allah SWT, surah AnNisa(4): 3 reads:

...then marry other women of your choice..."

Fourth, the moral aspect. With marriage, human is required to follow religious rules or norms, while other beings are not required to do so. So, marriage is a demarcation line that differentiates humans from other creatures to channel the same interests.

Fifth, the cultural aspect. In addition to differentiating humans from animals, marriage also distinguishes between civilized humans and savage humans, and between primitive humans and modern humans. Although in the primitive world there may have been rules of marriage, it is certain that our rules are much better than their rules. It shows that we have a better culture than ancient or primitive humans. 


\section{B. Underage Marriage and Legal Protection for Children}

Underage marriage is considered to be a serious problem because it raises controversy in society. Underage marriage is a problem and fact in a society that is still growing. Indonesia is one of the countries in the world with a relatively high rate of underage marriage. Underage marriage often occurs due to a number of reasons and views both legally, religion, tradition and culture in society ${ }^{15}$.

In society, there are many legal problems regarding underage marriages. This is considered to be a serious problem, because it raises controversy in society, not only in Indonesia but also an international issue. There are several factors that influence underage marriages, namely unwanted pregnancies in adolescents, the influence of social and religious customs or habits that legalize child marriage.

Child marriage is widely recognized as a dangerous socio-cultural practice, which is both a cause and a consequence of human rights violation. Underage marriage also undermines a girl's autonomous right, to live free from violence and coercion, and to obtain an education. Since a husband often expects his wife to bear children soon after marriage, underage marriage also allows sexual exploitation and endangers a girl's health. In addition, children born to underage mothers will start life at a disadvantage, thereby perpetuating the cycle of poverty.

In practice, child marriage for the Indonesian nation cannot be separated from the social, economic, cultural and religious conditions that develop in society. The influence of religion is also very strong in the implementation of child marriage in Indonesia. It is customary for the law to accommodate religious practices by exempting them from the general provisions that should be practiced. Underage marriages involve children and are arranged by family and community members who are involved in the matchmaking process. Child marriage is a form of tradition or custom as a result of a combination of social, cultural and economic factors ${ }^{16}$.

15 I.N. Inayati, "Perkawinan Anak Di Bawah Umur Dalam Persepktif Hukum, HAM Dan Kesehatan,” Jurnal Bidan "Midwife Journal 1, no. 1 (2015): 46-53.

16 S.D. Judiasih, Perkawinan Bawah Umur Di Indonesia. Bandung (Refika Aditama, 2018).
The result of a research in Bogor, for example, shows that the prevalence of underage marriages has relevance to the high divorce rate which is also dominated by couples aged 21-30 years, because even if the marriage is not recorded, due to insufficient age according to law, it still provides an opportunity to obtain legality with a legal attempt to apply for marriage istbat at Religious Court. In addition, emotional immaturity and unpreparedness in household caused high divorce rate among young couples ${ }^{17}$.

Meanwhile, the result of a research in Madura found that girls, especially those living in villages, were more vulnerable to being married off than girls in cities. The marriage often occurs in poor families. Women who do not continue school are more vulnerable to being married off than those who go to school. The reasons for child marriage are to reduce the economic burden on the parents, the parents' coercion on their children to get married and the culture of the community ${ }^{18}$.

The Indonesian government believes that getting married at an early age is one of the causes of maternal mortality because adolescent girls' reproductive organs are not yet well-established, so they cannot function optimally to give birth. However, early marriage drags many millennials. Data from the Central Statistics Agency (BPS) states that one in four girls in Indonesia were married at the age of less than 18 years from 2008 to 2015. Based on research data from the Center for Gender and Sexuality Studies at the University of Indonesia in 2015, it was revealed that the rate of early marriage in Indonesia was in the second highest in the Southeast Asia region. About 2 million out of 7.3 million Indonesian women under the age of 15 have married and dropped out of school. That number is expected to increase to 3 million people by $2030^{19}$.

Underage marriage is a violation of a child's right to enjoy the good times that will be remembered as an adult. Economic issues, parental coercion and community culture are inseparable parts of every legal incident of child

\footnotetext{
${ }_{17}$ E. Yumami, A., \& Suhartini, "Perkawinan Bawah Umur Dan Potensi Perceraian (Studi Kewenangan KUA Wilayah Kota Bogor," Jurnal Hukum IUS QUIA IUSTUM 1, no. 26 (2018): 193-211.

18 S. Trisilowati, D., Kurniasari, N.D., \& Hidayati, Budaya Perkawinan Anak Di Madura. (Madura, 2019).

19 “No Title," TEMPO.COM.
} 
marriage. State intervention through regulatory policies determining adult age limit for marriage is a must. This is a manifestation of the presence of the state to provide protection for every child. In addition, economic and cultural issues as well as customs in society must also be a concern.

The Convention of the Rights of The Child on November 20, 1989 has formulated several universal principles and norms regarding the position and rights of children which were then ratified by the Indonesian government through Presidential Decree Number 36 Year 1990 and Law No. 23 Year 2002 concerning Child Protection, the issue of which emphasizes the importance of the role of parents, society and the state in making efforts to protect and be responsible for children ${ }^{20}$.

Children's rights as part of human rights contained in Article 28 B paragraph (2) of the 1945 Constitution as a result of the second amendment states that every child has the right to live, grow and develop and is entitled to protection from violence and discrimination. The implementation of child protection must be based on the principles and norms contained in the Pancasila and the 1945 Constitution of the Republic of Indonesia as well as the basic principles of the Convention of the Rights of the Child which include the principle of non-discrimination, the principle of the best interests of the child, the principle of the right to life, survival and development, and the principle of respect for children's opinions.

The rights of the child from a legal perspective have universal aspects of children's interests. Putting the rights of the child in the view of the law gives an idea that the basic goal of human life is to build a human race that adheres to religious teachings. Thus, the rights of children in the view of law include legal aspects in a person's environment. In another action, Maulana Hasan Wadong says "a Muslim must be obedient in upholding children's rights by adhering to national law"21.

Child protection, as referred to in Article 3 of Law Number 23 Year 2002, aims to ensure the fulfillment of children's rights so that they can live, grow, develop and participate optimally in accordance with human dignity and protection

20 R. Lestari, "Implementasi Konvensi Internasional Tentang Hak Anak Di Indonesia," JOM FISIP 4, no. 2 (2017): 4.

${ }_{21}$ M.H. Wadong, Pengantar Advokasi Dan Hukum Perlindungan Anak (Jakarta: Grasindo, n.d.). from violence and discrimination, for the sake of realizing quality, noble and prosperous Indonesian children.

Law Number 16 Year 2019 concerning Amendments to Law Number 1 Year 1974 concerning Marriage, has made changes to the age limit for marriage, taking into account, first, that the state guarantees the right of citizens to form families and continue procreation through legal marriages, and guarantees the child's right to live, grow and develop and have the right to protection from violence and discrimination as mandated in the 1945 Constitution of the Republic of Indonesia. Second, that marriage at the age of children has a negative impact on children's growth and development and will disturb the fulfillment of children's basic rights such as the right to protection from violence and discrimination, children's civil rights, health rights, education rights, and children's social rights. Third, as an implementation of the decision of the Constitutional Court of the Republic of Indonesia Number 22/PUU-XV 2017, it is necessary to amend the provisions of Article 7 of Law Number 1 Year 1974 concerning Marriage, so that the formulation of Article 7 paragraphs (1), (2), (3), and (4) reads as follows:

(1) Marriage is only permitted if the man and woman have reached the age of 19 (nineteen) years;

(2) In the event of deviation from the age requirement as referred to in paragraph (1), the parents of the man and/or the parents of the woman may request dispensation to the Court on very urgent grounds accompanied by sufficient supporting evidence;

(3) The granting of dispensation by the court as referred to in paragraph (2) must listen to the opinions of the prospective bride and groom who are getting married.

(4) The provisions regarding the condition of one or both parents of the prospective bride and groom as referred to in Article 6 paragraph (3) and paragraph (4) shall also apply the provisions regarding the request for dispensation as referred to in paragraph (2) without prejudice to the provisions as referred to in Article 6 paragraph (6).

Marriage in the view of Islam is a human nature that is highly recommended for Muslims 
because marriage is a human instinct that must be fulfilled in a legitimate way, so as not to seek a path of error that plunges into the wrong path. Marriage orders in Islam are contained in the Qur'an and the Hadith of the Prophet Muhammad SAW. The issue of young marriage is often a polemic and controversy in society because there is still an assumption that it is recommended by religion. The terms and boundaries of underage marriage among Islamic legal experts are still different. In the perception of the scholars, a young marriage is a marriage that is carried out before reaching adulthood. Islamic Sharia does not limit a certain age for marriage, but implicitly, it requires that people who are getting married are really people who are ready mentally, physically and psychologically, mature and understand the meaning of a marriage which is a part of worship. ${ }^{22}$

The limitation on the adult age required in the Indonesian Marriage Law is relatively higher compared to several Islamic countries in the world, as shown in the table below:

Table 1.2. Comparison of the Age Limit for Marriage in Several Islamic Countries in the

World

\begin{tabular}{|c|c|c|}
\hline \multirow{2}{*}{ Country } & \multicolumn{2}{|c|}{ Age Limit for Marriage } \\
\hline & Man & Woman \\
\hline Indonesia & 19 & 19 \\
\hline Turkey & 17 & 15 \\
\hline Pakistan & 18 & 16 \\
\hline Morocco & 18 & 18 \\
\hline
\end{tabular}

However, a man who marries at the age of 19 does not necessarily have a steady income to support his family. The research results showed that the divorce rate was also largely due to economic factor that led to frequent disputes in married life.

\section{Application of the Lex Posterior Derogat Legi Priori Principle in Determining the Adult Age for Marriage}

Dworkin's thoughts on norms always come from morality. Dworkin believes that law is rooted in the principle of morality, therefore in the case of judges adjudicating cases with vague rules, judges must use hermeneutics, to judge these vague laws based on moral values and ideals of justice that lie

22 Y. Fatma, "Batasan Usia Perkawinan Dalam Hukum Keluarga Islam (Perbandingan Antar Negara Muslim; Turki, Pakistan, Maroko Dan Indonesia). Jurnal Ilmiah Syari'ah," Jurnal Ilmiah Syari'ah 18, no. 2 (2019): 117-135. behind these vague norms ${ }^{23}$.

Donald Dworkin then expressed his opinion as follows: In the case which is included in the Penumbra region, in fact there is no unique and correct answer as expressed by Dworkin. In cases where the rules are not clear, the judge has wider and stronger discretion. The judge makes the law and functions like a quasi-legislative capacity. They make decisions that they think are best on certain grounds and according to circumstances. Dworkin argues that even in tough cases, judges should know the principles of the law, not create them. Jury can also use discretion, but that is in a weak sense. Above all in all difficult cases, there are always unique and correct decisions ${ }^{24}$.

According to A. Hamid S. Attamimi, the establishment of Indonesian laws and regulations must also follow the guidelines and guidance provided by the ideals of a rule of law which is none other than Pancasila, which Attamimi terms as a guiding star, the principle of a rule of law and constitutionalism, in which a country adheres to the ideology of constitution. Furthermore A. Hamid. S. Attamimi says that if the division is related to formal and material principles, then the division is as follows:

1. Formal principles:

a. The principle of clear objectives;

b. The principle of the need for regulation;

c. The principles of the right organs/ institutions;

d. The principle of the correct content of the material;

e. The principle of enforceability;

f. The principle of recognition.

2. Material principles

a. Principle in accordance with the ideals of Indonesian law and fundamental state norms;

b. Principle in accordance with the basic laws of the country;

c. Principle in accordance with the principle of the state based on law;

\footnotetext{
23 S. Suhartono, "Hukum Positif Problematik Penerapan Dan Solusi Teoritiknya," Jurnal Ilmu Hukum 15, no. 2 (2020): 201-211.

24 Zafeer, Jurisprudenze: An Outline (International Law Book Services, 1994.
} 
d. Principle in accordance with the principle of governance based on the constitution $^{25}$.

The Directorate General of Laws and Regulations of the Ministry of Law and Human Rights of the Republic of Indonesia, in the Practical Guide to Understanding the Drafting of Laws and Regulations, states that in general the functions of laws and regulations can be divided into two groups:

1. Internal Function

Internal function is the function of regulating legislation as a legal sub-system (statutory law) to the rule of law system in general internally, laws and regulations carry out the function of creating law, function of legal reform, function of integration of legal pluralism, function of legal certainty. Internally, laws and regulations carry out several functions:

a. Function of creating law

The creation of laws that give birth to a generally accepted legal system is carried out or occurs in several ways, namely through judges' decisions, habits that grow as practices in the life of the community or the state, and laws and regulations as a written decision by an official or competent position environment that applies generally. Indirectly, law can also be formed through legal teachings that are accepted and used in the establishment of law.

b. Function of legal reform

Laws and regulations are an effective instrument in legal reform compared to the use of customary law or jurisprudential law. Laws and regulation perform not only the function of reforming (existing) laws and regulations. Laws and regulations can also be used as a means of reforming jurisprudence of customary law or adat law. The function of reforming laws and regulations, among others, is in the context of replacing laws

25 M.F.I. Soeprapto, Ilmu Perundang-undangan (Yogyakarta: Kanisius, 2007). and regulations from the era of the Dutch East Indies government. It is no less important to reform national laws and regulations (created after independence) that are no longer in line with new needs and development. In the field of customary law or adat law, laws and regulations have the function of replacing customary law or adat law that is inconsistent with new reality. The use of laws and regulations as an instrument for reforming customary law or adat law is very important, because in certain cases the latter two laws are very rigid to change.

c. Function of integration of legal system pluralism

At present, various legal systems are still in effect, namely: the continental legal system, the adat law system, the religious law system (especially Islam) and the national legal system. The pluralism of the legal system that is currently in effect is one of the colonial legacies that must be rearranged. The rearrangement of various legal systems is not intended to eliminate various legal systems, especially legal systems that exist as a reality that is adhered to and maintained in public relations. The development of a national legal system is in the framework of integrating these various legal systems so that they are arranged in a harmonious order with each other. Regarding pluralism, the rule of law is entirely dependent on the legal needs of the community. The rule of law may differ between different groups of people, depending on the circumstances and needs of the people concerned.

d. Function of legal certainty

Legal certainty is an important principle in legal action and law enforcement. It is common knowledge that laws and regulations can provide higher legal certainty than customary law, adat law or jurisprudence law. However, it should be noted that legal certainty in laws and regulations is not merely put in its written form. 
2. External Function

External function is the relationship between laws and regulations and their place of effect. This external function can be referred to as a legal social function, which includes the function of change, the function of stabilization, and the function of convenience. Thus, this function can also apply to customary law, adat law, or jurisprudence law. For Indonesia, this social function will be played more by laws and regulations, due to various considerations that have been mentioned earlier. This social function can be distinguished into:

a. Function of change

For a long time in legal education circles this function of change has been introduced, namely law as a means of renewal. Laws and regulations are created or formed to encourage changes in society in the economic, social, and cultural fields. A "patrilineal" or "matrilineal" society can be pushed towards a "parental" society through marriage laws and regulations.

b. Function of stabilization

Laws and regulations can also function as stabilization. Laws and regulations in the field of crime, in the field of order and security are principles which are primarily aimed at ensuring the stability of society. Stability principles can also include economic activities, such as work arrangements, arrangements for trade procedures and others. Likewise, in the field of supervision of external culture, it can also function to stabilize the existing socio-cultural system.

c. Function of convenience

Laws and regulations can also be used as a means of regulating various facilities. Laws and regulations that contain incentive provisions such as tax relief, postponement of tax imposition, simplification of licensing procedures, capital structure in investment are the principles of convenience. However, it should be noted, not forever, that the regulation on convenience will immediately lead to the goal of providing convenience. In investment, for example, in addition to the facilities mentioned above, other requirements are also needed, such as political stability, economic facilities and infrastructure, employment, and so on ${ }^{26}$.

In general, there are various general principles of law that must be considered and required in the establishment of laws and regulations (Yusnani et al, 2017), namely:

1. The principle of lex superiot derogate legi inferiori, namely laws and regulations of higher level take precedence over lower laws and regulations and vice versa.

2. The principle of lex specialis derogate legi generali, namely that specific laws and regulations take precedence over general laws and regulations.

3. The principle of lex posterior derogate legi priori, new laws and regulations take precedence over the previous one.

4. The principle of lex neminem cogit ade impossobilia, namely laws and regulations that do not force someone to do something that is impossible to do or is often referred to as the principle of decency.

5. The principle of lex perfecta, namely laws and regulations not only prohibiting an action but also declaring the prohibited act null and void.

6. The principle of non retroactive, namely laws and regulations are not meant to apply retroactively because it will create legal certainty.

To resolve conflict of norms, according to Gert Frederick Malt, several methods can be used, namely the principle of preference, and methods or several other ways, which are further stated as follows:

Traditionally there are three general principles that can be used in resolving some conflicts in statutory science, namely in the most general formulation: a). the principle of lex posterior: lex posterior derogate legi priori, namely: the latter overrides the previous provisions; $b$ ). the

\footnotetext{
${ }_{26}$ T.H Simatupang, "Mendudukkan Konsep Executive Review Dalam Sistem Hukum Ketatanegaraan Indonesia," Jurnal Penelitian Hukum DE JURE 19, no. 2 (2017): 217-230.
} 
principle of lex specialis: lex specialis derogate legi generali, namely: more specific provisions override general provisions; c). the principle of lex superior: lex superior derogat legi inferior, namely: the higher provisions override the lower provisions ${ }^{27}$.

The principle of lex posterior: lex posterior derogate legi priori means that the new regulatory norm overrides the old norm. As an example of the norms of Law Number 23 Year 2014 concerning Regional Government, regarding the authority to grant coal mineral mining permits overriding Law Number 4 Year 2014 concerning Mineral and Coal Mining. So that the authority to grant coal mineral mining permits that originally rests with the Regency/City Government is transferred to the authority of the Province based on the Regional Government Law $^{28}$.

The principle of lex posterior derogat legi priori, namely the new laws and regulations paralyze the old regulations. It adheres to several principles, namely:

1. The new rule of law must be equal to or higher than the old rule of law, and;

2. The new rule of law and the old rule of law regulate the same aspects (Mertokusumo, 1993).

This principle has the intention of preventing dualism which can lead to legal uncertainty. With the existence of the lex posterior derogat legi priori principle, the provisions governing the revocation of laws and regulations are not really that important. By law, the same old provisions will no longer apply when the new rule of law comes into effect ${ }^{29}$.

In the context of the adult age limit in Indonesia which is regulated in various laws and regulations, by applying the lex posterior derogat legi priori principle, especially adulthood to have a marriage, what is used is Law Number 16 Year 2019 concerning Amendments to Law Number 1 Year 1974 concerning Marriage, which is 19 years for both women and men, with consideration of

27 G. F. Malt, Methods For The Solution Of Conflict Between Rules In ASystem of Positive Law (Amsterdam: Kluwer Law and Taxation Publisher Deventer/Bostom, 1992).

28 Suhartono, "Hukum Positif Problematik Penerapan Dan Solusi Teoritiknya."

29 B. Manan, Hukum Positif Indonesia (Yogyakarta, 2004). the same degree of laws and regulations (Law), and Law Number 16 Year 2019 concerning amendments to Law Number 1 Year 1974 is Law that was born later (most recently) which regulates the norms of marriage.

\section{CONCLUSION}

Islamic family law cannot be separated from the history of the legal system in Indonesia from the time of Dutch colonialism to the present which always involves three parties, namely the interests of religion, the state and women. Underage marriage is influenced by many factors, especially economic issues, parental coercion and community culture. Based on the lex posterior derogat legi priori principle, the determination of the adult age limit for a child for the purpose of marriage is 19 years, for both women and men, as regulated in Article 7 of Law Number 16 Year 2019 concerning Amendments to Law Number 1 Year 1974 concerning Marriage.

\section{SUGGESTION}

In the future, further research is needed regarding the maturity of a person to marry in terms of psychological and economic aspects. This is important because maturity to marry for a man must also consider financial readiness. Financially, the age of 19 for a man, as a candidate for head of the family, who will meet the needs of his household, is not yet well-established enough to support his wife and children in the future.

\section{ACKNOWLEDGMENT}

On this occasion the researcher would like to thank DE JURE Legal Research Journal for providing opportunities, space and chance to share a little thought in the scientific space, especially in the realm of Civil Law and Family Law in Indonesia.

\section{BIBLIOGRAPHY}

Bukido, R. \& Wantu, F.M. "Synchronize the Different Law Rules Study of Law Number 16 Year 2019 and Law Number 35 Year 2014." Journal of Legal, Ethical and Regulatory Issues 23 (2020): 1-9.

Evi Djuniarti. "Perkawinan 'Padagelahang' Serta Asepk Hukum Pembagian Harta Warisannya 
Di Bali." Jurnal Penelitian Hukum DE JURE 20, no. 3 (2020): 459-471.

Fatma, Y. "Batasan Usia Perkawinan Dalam Hukum Keluarga Islam (Perbandingan Antar Negara Muslim; Turki, Pakistan, Maroko Dan Indonesia). Jurnal Ilmiah Syari'ah." Jurnal Ilmiah Syari'ah 18, no. 2 (2019): 117-135.

Hakim, R. Hukum Perkawinan Islam. Bandung: Pustaka Setia, 2000.

Inayati, I.N. "Perkawinan Anak Di Bawah Umur Dalam Persepktif Hukum, HAM Dan Kesehatan." Jurnal Bidan "Midwife Journal 1, no. 1 (2015): 46-53.

Judiasih, S.D. Perkawinan Bawah Umur di Indonesia. Bandung. Refika Aditama, 2018.

Lestari, R. "Implementasi Konvensi Internasional Tentang Hak Anak Di Indonesia." JOM FISIP 4, no. 2 (2017): 4.

Malt, G. F. Methods For The Solution Of Conflict Between Rules In A System Of Positive Law. Amsterdam: Kluwer Law and Taxation Publisher Deventer/Bostom, 1992.

Manan, B. Hukum Positif Indonesia. Yogyakarta, 2004.

Masriani, Y.T. Pengantar Hukum Indonesia. Jakarta: Sinar Grafika, 2004.

Mulyadi. Hukum Perkawinan Islam. Semarang: Badan Penerbit Universitas Diponegoro, 2000.

Romlah R. "Pembaruan Hukum Keluarga Islam Di Indonesia Tentang Keabsahan Akad Bagi Wanita Hamil." Jurnal Al-Adalah Institut Agama Islam Negeri Raden Intan Lampung 13, no. 1 (2016): 23-38.

Simatupang, T.H. "Mendudukkan Konsep Executive Review Dalam Sistem Hukum Ketatanegaraan Indonesia." Jurnal Penelitian Hukum DE JURE 19, no. 2 (2017): 217-230.

Soeprapto, M.F.I. Ilmu PerundangUndangan. Yogyakarta: Kanisius, 2007.

Suhartono, S. "Hukum Positif Problematik Penerapan Dan Solusi Teoritiknya." Jurnal Ilmu Hukum 15, no. 2 (2020): 201-211.

Taufik H. Simatupang. "Disharmoni Peraturan Perundang-Undangan Di Bidang Pengawasan
Perwalian di Indonesia (Lintas Sejarah Dari Hukum Kolonial Ke Hukum Nasional)." Jurnal Penelitian Hukum DE JURE 20, no. 2 (2020): 221-232.

Trisilowati, D., Kurniasari, N.D., \& Hidayati, S. Budaya Perkawinan Anak Di Madura. Madura, 2019.

Wadong, M.H. Pengantar Advokasi Dan Hukum Perlindungan Anak. Jakarta: Grasindo, n.d.

Yumami, A., \& Suhartini, E. "Perkawinan Bawah Umur Dan Potensi Perceraian (Studi Kewenangan KUA Wilayah Kota Bogor." Jurnal Hukum IUS QUIA IUSTUM 1, no. 26 (2018): 193-211.

Zafeer. Jurisprudenze: An Outline (International Law Book Services, 1994.

Lihat Pasal 1 Angka 26 Undang-Undang Nomor 18 Tahun 2003 Tentang Ketenagakerjaan, n.d.

Lihat Pasal 1 Angka 4 Dan Angka 5 UndangUndang Nomor 11 Tahun 2012 Tentang Sistem Peradilan Pidana Anak, n.d.

Lihat Pasal 1 Angka 5 Undang-Undang Nomor 39 Tahun 1999 Tentang Hak Asasi Manusia, n.d.

Lihat Pasal 1 Ayat (1) Undang-Undang Nomor 23 Tahun 2002 Tentang Perlindungan Anak, n.d.

Lihat Pasal 39 Dan Pasal 40 Undang-Undang Nomor 30 Tahun 2004 Tentang Jabatan Notaris, n.d.

Lihat Pasal 47 Ayat (1) Undang-Undang Nomor 16 Tahun 2019 Tentang Perubahan UndangUndang Nomor 1 Tahun 1974 Tentang Perkawinan, n.d.

Lihat Pasal 98 Ayat (1) Instruksi Presiden Nomor 1 Tahun 1991 Tentang Kompilasi Hukum Islam, n.d.

"No Title." TEMPO.COM. 